\title{
Ksiądz Profesor Jerzy Bajda, kapłan, ojciec duchowny, profesor seminarium duchownego w Tarnowie
}

Uwagi wstępne

Refleksja nad nauczaniem ks. prof. Jerzego Bajdy musi się zacząć od pytania o jego korzenie. Dlatego wróćmy do informacji biograficznych i środowiska rodzinnej diecezji tarnowskiej.

\section{1. Środowisko rodzinne}

Ksiądz Jerzy Bajda urodził się 11 maja 1928 w Krakowie, w rodzinie Stefana i Józefy z d. Jędryka. Wraz z rodzeństwem wychował się w Bochni, w której też uczęszczał do szkoły. Ojciec pracował jako urzędnik, najpierw w Krakowie, a potem w starostwie powiatu bocheńskiego. Bajdowie mieli siedmioro dzieci: sześciu synów i jedną córkę 1 .

1 Na podstawie informacji uzyskanych od bratanka Ryszarda Bajdy podaję ich dane: Henryk, ur. w 1916, zm. 2001; Stefan, ur. 1922, zm. 1964; Marian ur. 1924, mieszka w USA
- Uwagi wstępne

- Środowisko rodzinne

- Seminarium duchowne w Tarnowie

- Placówki duszpasterskie i studia w Lublinie

- Ojciec duchowny w seminarium duchownym w Tarnowie - Profesor teologii moralnej - Uwagi końcowe 
Bochnia to średniowieczne miasto z tradycjami kopalni soli, starsze od Wieliczki, w XIX wieku siedziba biskupa i pierwszego na obszarze dzisiejszej diecezji tarnowskiej seminarium duchownego, założonego w 1822 roku przez biskupa Grzegorza Tomasza Zieglera ${ }^{2}$. Kościół św. Mikołaja - pełniący w XIX wieku rolę prokatedry - znany był przede wszystkim jako sanktuarium Matki Bożej Różańcowej.

Rodzina Bajdów mieszkała na ul. Brzeźnickiej, blisko cegielni i kaplicy na tzw. Murowiance. Bochnia zaś to ukochane miasto Jerzego. Było ono jak pisze

otoczone nie tylko sympatycznymi wzgórzami, ale przede wszystkim duchową opieką Matki Bożej królującej (bo koronowanej), w cudownej Kaplicy Różańcowej kościoła św. Mikołaja. Z wieży kościelnej w miesiącu maju rozlegały się chwytające za serce melodie pieśni maryjnych, wygrywane na instrumentach dętych orkiestry górniczej. W lipcu kto żyw uczestniczył w pielgrzymce do Łapczycy na uroczysty odpust Matki Bożej Szkaplerznej. W sierpniu budziły nas śpiewy grup pielgrzymkowych zdążających „na bliższe ku Kalwarii Zebrzydowskiej. Największą atrakcją dla młodego chłopca były jednak uroczyste Msze święte w kaplicy na Murowiance. Mała kaplica Matki Bożej Anielskiej nie mogła oczywiście pomieścić uczestników liturgii, którzy schodzili się ze wszech stron przez pola barwnym sznurem, konkurując z malowniczością krajobrazu. Tak było oczywiście na Matkę Bożą Anielską, tak było na Wniebowzięcie. Tłum mieszał swoje śpiewy i modlitewne szepty z łagodnym szumem drzew i szmerem nigdy nie wysychającego źródełka. Byliśmy przekonani, że Matka Boża wszystkich wysłuchuje i napełnia serca swoich dzieci Bożym pokojem ${ }^{3}$.

Po wybuchu II wojny światowej - mając 11 lat - wraz z rodziną udał się na wschód; w Przemyślu znaleźli się na terenie zajętym przez armię

z żoną i dziećmi; Jerzy ur. 11 maja 1928; Zdzisław, ur. 1930, zm. 1983; Stanisław, zm. w dzieciństwie (1941); Krystyna, ur. ?, szarytka.

2 Por. R. Banach, Poczqtki Seminarium Duchownego w Tarnowie, „Tarnowskie Studia Teologiczne" 5, (1972), s. 183-198.

3 J. Bajda, Wdzięczność i radość. Wspomnienia z okazji złotego jubileuszu święceń kapłańskich 1954-2004,. Tuchów 2004, s. 23-24. 
sowiecką. To, że udało im się stamtąd wrócić do Bochni, uważał niemal za cud.

Wojna zburzyła sielankę życia młodzieńczego. Nie osłabiła ducha modlitwy. Owszem, wiele okoliczności i wydarzeń tym bardziej skłaniało chłopca do ufnego powierzania Bogu trudnych spraw.

Kiedy nie wiedzieliśmy, co się stało z jednym z moich braci (starszym o sześć lat), a było uzasadnione podejrzenie, że dostał się w sidła NKWD, nasza Mama zachęciła nas do odmawiania różańca. Po dłuższym czasie (chyba po dwóch latach), otrzymaliśmy tajemniczy list - z Afryki: to był list od niego, pisany w sposób zaszyfrowany. List przyszedł oficjalnie na nasz adres, a była to okupacja! Matka Boża czuwała nad naszym bratem także później, kiedy wraz z armią polską pod dowództwem gen. Andersa brał udział w kampanii afrykańskiej, a potem w lądowaniu w Italii aż do Monte Cassino ${ }^{4}$.

Po wojnie brat przysłał Jerzemu swój pamiątkowy różaniec, który towarzyszył mu w tej niebezpiecznej kampanii. Również drugi brat Marian, jedyny obecnie żyjący (w USA), wędrował w czasie wojny, a we Włoszech spotkał się nieoczekiwanie $\mathrm{z}$ bratem Stefanem.

Wspominając swoje minione lata przed jubileuszem 50-lecia kapłaństwa sam Ksiądz Profesor składał podziękowanie Bogu za to,

że trzymał nas przy życiu - i przy Sobie - przez tyle lat, w ciągu których przecież działo się tyle rzeczy - poważnych i niebezpiecznych, niezwykłych i przełomowych. Nikt $\mathrm{z}$ nas nie może narzekać, że żył w czasach mało ciekawych, i nikt nie ma wątpliwości, że Opatrzność prowadziła nas dziwnymi drogami - ku urzeczywistnieniu Bożych planów 5 .

Najmłodszy brat Jerzego - Stanisław - zmarł jako dziecko w 1941 roku, w czasie II wojny światowej. Pozostali bracia wybrali później życie rodzinne, Jerzy zaś wraz z siostrą Krystyną - służbę Bożą. Swój wybór uzasadniał w kilku zdaniach we wspomnieniach jubileuszowych, pisanych po wielu latach.

4 J. Bajda, Wdzięczność i radość.., dz. cyt., s. 24.

5 J. Bajda, Wdzięczność i radość.., dz. cyt., s. 23. 


\section{Seminarium duchowne w Tarnowie}

Wojna i sytuacja, jaka zapanowała po wojnie, zmuszała do poważnych przemyśleń i podjęcia decyzji adekwatnych do powagi wyzwań, przed jakimi stał nasz naród. Przed maturą cała klasa wytrwale uczestniczyła w nabożeństwach majowych, kontynuując tę praktykę także po maturze. Po złożeniu egzaminu dojrzałości w Bochni w 1949 roku Jerzy wstąpił do Wyższego Seminarium Duchownego w Tarnowie. Do kapłaństwa przygotowywał się bardzo odpowiedzialnie. Długo zastanawiał się, jaki wybrać kierunek życia, ponieważ pociągało go wiele rzeczy kojarzących się z literaturą, sztuką, nauką. Przez cały miesiąc modlił się na różańcu, prosząc Matkę Bożą o światło co do wyboru kierunku życiowego, czyli powołania. Dopiero spowiednik rozwiał jego wątpliwości, i w końcu jako jeden z ostatnich złożył podanie o przyjęcie go do seminarium duchownego w Tarnowie.

Uważałem - pisze - że jest zbyt wiele poważnych spraw w życiu naszej Ojczyzny, aby zamknąć się wyłącznie w kręgu osobistych zamiłowań i upodobań. Sądziłem, że jest to czas, w którym trzeba robić coś bardzo ważnego, a czymś takim, co było Polsce bardzo potrzebne, to - według mnie - było kapłaństwo, czyli współdziałanie z Bogiem w celu ratowania świata ${ }^{6}$.

W czasie pobytu w seminarium odbywał równocześnie studia teologiczne w Instytucie Teologicznym w Tarnowie. Trwały one pięć lat. Według modelu austriackiego, który wciąż obowiązywał w diecezji tarnowskiej, Instytut Teologiczny miał charakter samodzielnego wydziału uniwersyteckiego, ściśle związanego $\mathrm{z}$ diecezjalnym seminarium duchownym ${ }^{7}$. Jerzy uczył się dobrze. Koledzy uważali, że niekiedy swoją wiedzą dorównywał profesorom. A wykładowców tegoż Instytutu Teologicznego było wtedy osiemnastu, w tym jedenastu z tytułem profesorów zwyczajnych (m.in. ks. Stanisław Adamczyk, ks. Jan Bochenek i ks. Stanisław Łach).

6 J. Bajda, Wdzięczność i radośćc.., dz. cyt., s. 24.

7 Por. R. Banach, Powstanie i organizacja Seminarium Duchownego w Tarnowie, "Rocznik Tarnowski" (1990), s. 37-40; A. Żurek, Studia o charakterze teologicznym i religijnym w diecezji tarnowskiej od początków jej dziejów. Instytucje, w: Dzieje diecezji tarnowskiej, t. 2 Instytucje i wydarzenia, red. A. Gąsior, J. Królikowski, Tarnów 2012, s. 209-226. 
Nadzór nad seminarium sprawował biskup tarnowski, wybitny uczony w dziedzinie filozofii, Jan Stepa, jego sufraganem był bp Karol Pękala. Rektorem seminarium w tych latach był ks. dr Władysław Węgiel, wicerektorem ks. dr Stanisław Łach, ojcem duchownym zaś ks. dr Michał Blecharczyk, późniejszy proboszcz w Bochni, a następnie biskup pomocniczy diecezji tarnowskiej. W seminarium było też dwóch prefektów: ks. dr Józef Brudz i ks. dr Józef Pasterski,

W poczuciu odpowiedzialności za przyszłą pracę kapłańską Jerzy zabrał się do pracy nad sobą, by pogłębić swoje życie duchowe.

Postanowił nie realizować w życiu swoich ambicji, tylko wolę Bożą. Pan Bóg niejednokrotnie ,sprawdzał szczerość” mojego postanowienia - pisze w swoich wspomnieniach jubileuszowych:

Kiedy po otrzymaniu święceń otrzymałem skierowanie na placówkę duszpasterską (wikariat w parafii mieleckiej), uznałem, że jest to dobra decyzja. Po dwóch latach pokazała się niespodziewanie możliwość podjęcia dalszych studiów. Ówczesny Ordynariusz Biskup Jan Stepa postawił mi pytanie o to, jaka dziedzina nauki najbardziej mi się podoba. Niechętnie, choć szczerze wyznałem, że filozofia, ewentualnie dogmatyka. Kiedy wyjawiłem swoje myśli, usłyszałem decyzję: „W takim razie ja kieruję księdza na prawo kanoniczne". Taka widocznie była wola Boża ${ }^{8}$.

\section{Placówki duszpasterskie i studia w Lublinie}

9 maja 1954 roku Jerzy otrzymał święcenia kapłańskie z rąk bpa Karola Pękali, zaś 31 sierpnia 1954 został mianowany wikariuszem w parafii św. Mateusza w Mielcu. W 1956 roku został skierowany przez biskupa tarnowskiego Jana Stepę na studia specjalistyczne w zakresie prawa kanonicznego na KUL, gdzie w 1959 roku uzyskał magisterium z prawa kanonicznego na podstawie pracy: Prawowitość państw pogańskich w traktatach Pawła Włodkowica.

8 Ks. J. Bajda, Wdzięczność i radość..., dz. cyt., s. 25. Ks. Franciszek Bondek wspomina, że ks. Bajda opowiadał przy nim swojemu koledze ks. Szczurkowi, proboszczowi w Sobolowie, jakoby powiedział biskupowi, że nie lubi prawa i dlatego został skierowany na prawo. 
W latach 1960-1962 pełnił funkcję wikariusza w Gorlicach, kontynuując równocześnie studia na wydziale prawa kanonicznego w Lublinie. W Gorlicach miał równocześnie przygotować pracę doktorską.

Był to jednak czas trudny dla kapłanów pracujących jako katecheci.

Kiedy usiłowano nam narzucić obowiązkową rejestrację punktów katechetycznych, co oznaczało poddanie katechizacji pod kontrolę partii komunistycznej, oczywiście nie mogliśmy się zgodzić. Zaczęliśmy uczyć „nielegalnie” - jak nam mówiono - i wtedy ścigano nas kolegiami, choć naprawdę to oni działali nielegalnie i wbrew prawu Bożemu. Mam tę satysfakcję, że ani raz nie zapłaciłem kary wyznaczonej przez kolegium. A uczyliśmy w warunkach trudnych, o czym można by dużo pisać szczegółowo. Te okoliczności wrogie dla religii wspaniale mobilizowały ludzi naprawdę wierzących i mogłem budować się wiarą i poświęceniem tych parafian, którzy narażając się na wielkie przykrości, dawali w swoich skromnych domach miejsce dla głoszenia Ewangelii ${ }^{9}$.

Ponieważ doktorat sam się nie pisał, a praca duszpasterska go wciągała, po dwóch latach ks. Jerzy otrzymał urlop z pracy duszpasterskiej, by mógł sfinalizować doktorat. A temat nie miał łatwy. „Ale jakoś wybrnąłem” - pisze. 28 czerwca 1963 uzyskał stopień doktora prawa kanonicznego na podstawie pracy : Prawowitość władztw pogańskich w nauce Pawła Włodkowica, napisanej pod kierunkiem prof. dr. hab. Leszka Winowskiego.

W czasie tego urlopu przez pół roku przebywał w parafii katedralnej, by „przypomnieć sobie uroki pracy katechetycznej”. Potem został wytypowany na dalsze studia do Rzymu, i to - jak pisze - na „bardzo ciekawy kierunek, mianowicie na teologię liturgii". Jednak nie otrzymał paszportu. W tej sytuacji bp Jerzy Ablewicz mianował go ojcem duchownym w seminarium.

\section{Ojciec duchowny w seminarium duchownym w Tarnowie}

5 września 1963 roku objął obowiązki ojca duchownego w Wyższym Seminarium Duchownym w Tarnowie, które pełnił do września 1966 roku. Jego

9 J. Bajda, Wdzięczność i radość..., dz. cyt., s. 25 
podstawowym obowiązkiem było głoszenie konferencji ascetycznych dla kleryków w niedziele i czwartki oraz święta, a także indywidualne dyrekcje $\mathrm{z}$ każdym alumnem.

Większość wychowanków zgodnie przyznaje, że konferencje ks. Jerzego Bajdy ojca duchownego były bardzo starannie przygotowane i trudne. Natomiast bezpośredni kontakt z ojcem duchownym był bardzo serdeczny i zachęcał do pracy nad sobą.

Ale trzeba jeszcze wspomnieć, że wspomniany okres to był bardzo trudny czas. Właśnie w roku 1963 z tarnowskiego seminarium, podobnie jak z wielu innych seminariów w całej Polsce, wzięto kleryków do wojska. Z Tarnowa powołano ich sześćdziesięciu trzech. Oprócz żmudnej, a zarazem niezwykle delikatnej pracy nad kształtowaniem sumień kleryków pozostałych w seminarium trzeba było jeździć po całej Polsce i odwiedzać kleryków-żołnierzy. Ojciec duchowny Jerzy też tak czynił. Warto zwrócić uwagę, że był to czas przygotowań do obchodów tysiąclecia chrztu Polski, a także czas Soboru Watykańskiego II oraz wprowadzenia w życie reform tegoż soboru. Ks. Jerzy po latach oceniał to bardzo delikatnie w swoich wspomnieniach ${ }^{10}$. O problemach, jakie pojawiły się w czasie jego pełnienia funkcji ojca duchownego, pisze bardzo powściągliwie:

Ponowny pobyt w Seminarium miał swoje blaski i cienie. Panował wtedy ogólny ferment „,reform posoborowych”. Próbowaliśmy to i owo unowocześnić i poprawić z tego, co przekazała nam tradycja; nie zawsze to miało dobry skutek. Dziś bardziej chłodno i trzeźwo patrzę na tamte plany i marzenia

- pisze w we wspomnieniach jubileuszowych ${ }^{11}$.

\section{Profesor teologii moralnej}

Równocześnie, w czasie pełnienia funkcji ojca duchownego, otrzymał zlecenie prowadzenia wykładów z teologii moralnej. Jego wykłady dotyczyły podstaw

10 J. Bajda, Wdzięczność i radość..., dz. cyt., s. 26.

11 J. Bajda, Wdzięczność i radość..., dz. cyt., s. 26. 
teologii moralnej („Principia”). Ponieważ jako kanonista nie miał studiów specjalistycznych z teologii moralnej, został przez bpa Jerzego Ablewicza skierowany na Papieski Wydział Teologiczny w Krakowie celem uzyskania licencjatu z teologii moralnej.

Pomimo że bycie ojcem duchownym stanowiło par excellence formę duszpasterstwa, znów zaczęła mnie prześladować perspektywa pracy naukowej. Równocześnie nastąpiły pewne fakty, które utrudniły mi jasne rozpoznanie woli Bożej: nauka znów połączyła się z duszpasterstwem ${ }^{12}$.

Tak dyskretnie nazywa to, co dla nas kleryków było wielkim wydarzeniem, że zwolniony został przez biskupa ze stanowiska ojca duchownego.

Zwolnienie ks. Jerzego z funkcji ojca duchownego nie oznaczało, że bp Jerzy Ablewicz go nie doceniał. W dalszym ciągu prowadził wykłady i przygotowywał się do licencjatu z teologii moralnej. Po uzyskaniu licencjatu 20 czerwca 1968 roku na podstawie pracy: Pojęcie powołania chrześcijańskiego w konstytucji dogmatycznej „Lumen gentium” prowadził wykłady z teologii moralnej zarówno w seminarium duchownym w Tarnowie (1965-1973) jak też na życzenie kardynała Karola Wojtyły na Papieskim Wydziale Teologicznym w Krakowie (1 X 1969-30 VI 1974) w wymiarze trzech godzin tygodniowo.

24 lipca 1968 roku otrzymał nominację na diecezjalnego referenta do spraw ekumenizmu, ponadto z dniem 1 września 1969 roku objął urząd rektora kościoła w Koszycach Małych, który sprawował do 1972 roku. „Zostałem zamianowany proboszczem w tworzącej się parafii przy kapliczce SS. Urszulanek w Koszycach Małych koło Tarnowa" - pisze we wspomnieniach ${ }^{13}$. Od 13 marca 1972 roku był również członkiem diecezjalnej rady duszpasterstwa rodzin.

Przeżywałem pewne trudności w koordynacji dwojakiego typu obowiązków. Duszpasterstwo wciągało mnie bardzo i bałem się, że praca nauko-

12 J. Bajda, Wdzięczność i radość..., dz. cyt., s. 26.

Sam o tym nie wspomina, jak to się stało. Tymczasem my jako klerycy dowiedzieliśmy się - a ja byłem wtedy jego wychowankiem - że do Księdza Biskupa Jerzego Ablewicza dotarła informacja, jakoby ojciec duchowny gorszył kleryków, bo bez sutanny z seminarium wyjeżdżał na rowerze. Wprawdzie wtedy jeszcze żaden inny przełożony Seminarium nie pokazywał się nam bez sutanny, ale zachowanie ojca duchownego wyglądało w naszych oczach zupełnie naturalnie.

13 J. Bajda, Wdzięczność i radość..., dz. cyt., s. 26. 
wa zejdzie całkiem na margines. Mobilizował mnie bardzo kontakt z Krakowem; tamto środowisko było dla mnie bardzo interesujące. Mogłem uczestniczyć w seminariach i sesjach naukowych organizowanych przez kard. Karola Wojtyłę. Nie muszę mówić, jak bardzo dodatnio ten kontakt wpływał na mojego ducha, na rozumienie spraw naukowych (teologicznych) jak i ogólnych problemów Kościoła, dających znać o sobie w trudnym okresie posoborowym. Człowiekiem z kręgu krakowskich osobistości, który wprowadzał mnie bezpośrednio w rozumienie aktualnych problemów teologicznomoralnych, był (najpierw Prałat a potem Biskup) Stanisław Smoleński. Podziwiałem jego ogromną szlachetność w spojrzeniu na sprawy Kościoła i Narodu. Wszyscy jednak byliśmy pod niezwykłym urokiem osoby Kardynała Wojtyły, który wprowadził nas w tajniki dyskusji teologicznomoralnych toczących się w Kościele przed - i po - opublikowaniu epokowej encykliki Humanae vitae. Wydawało się, że tak będzie już zawsze, ale Opatrzność przygotowywała pewną niespodziankę ${ }^{14}$.

Tą niespodzianką było przeniesienie do Warszawy na Akademię Teologii Katolickiej w 1972 roku. Tym razem Opatrzność Boża posłużyła się ks. profesorem Stanisławem Olejnikiem, który użył wszelkich sposobów, by ks. Jerzy Bajda znalazł się w Warszawie. Następnym narzędziem Opatrzności był ks. Abp Kazimierz Majdański, który poprosił ks. Jerzego z wykładami w tworzącym się Instytucie Badań nad Rodziną w Łomiankach. Ks. Jerzy określa to krótko: „I tak wsiąkłem w Instytut”... ${ }^{15}$.

\section{Uwagi końcowe}

Do Tarnowa ks. Jerzy Bajda wrócił na stałe dopiero jako emeryt, w 2011 roku, gdy zaczęły się poważne kłopoty zdrowotne. Zamieszkał w Domu Księży Emerytów w Tarnowie przy ul. Pszennej 7,gdzie mocował się z chorobą nowotworową. Starał się pełnić swą posługę kapłańską, podejmował nawet głoszenie prelekcji, o ile mu siły pozwalały.

14 J. Bajda, Wdzięczność i radość..., dz. cyt., s. 26.

15 J. Bajda, Wdzięczność i radość..., dz. cyt., s. 27 
Zmarł 10 grudnia 2012 roku. Msza św. pogrzebowa była celebrowana w dniu 14 grudnia w bazylice mniejszej w Bochni, a następnie ciało zmarłego złożono na cmentarzu komunalnym przy ul. Orackiej w Bochni. Uroczystościom pogrzebowym przewodniczył biskup tarnowski Andrzej Jeż.

Za gorliwie pełnioną posługę kapłańską ks. Bajda otrzymał 18 stycznia 1966 roku diecezjalne odznaczenie Expositorium Canonicale, a 2 grudnia 1978 roku diecezjalny przywilej Rochetto et Mantoletto. Został także obdarzony w dniu 9 czerwca 1992 roku godnością kapelana Jego Świątobliwości.

Wspomnienia jubileuszowe spisane osobiście w 2004 roku są dobitnym świadectwem, jakim ks. prof. Jerzy Bajda był kapłanem. Jego postawa kapłańska przejawiała się nawet $\mathrm{w}$ czynnościach, które z kapłaństwem nie miały bezpośrednio związku. Wydaje mi się, że tą postawą oddziaływał szczególnie na kleryków, gdy pełnił funkcję ojca duchownego i profesora teologii moralnej w Tarnowie. Swoją osobowością i całkowitym oddaniem posłudze kapłańskiej formował nas bardziej niż trudnymi konferencjami ascetycznymi.

Posługując się określeniem samego Księdza Profesora, że kapłaństwo to współdziałanie $\mathrm{z}$ Bogiem w celu ratowania świata, można zaryzykować zdanie, że był takim kapłanem całym sobą i przez całe życie. Był ojcem duchownym tylko trzy lata, ale poprzez hymn, który napisał dla seminarium duchownego w Tarnowie, trwa duchem nadal. 